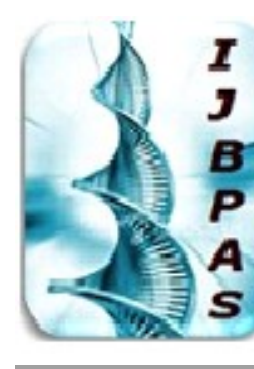

International Journal of Biology, Pharmacy and Allied Seiences (IJBPAS)

'A Bridge Botwen Caboratory and Q Qndor'

WwW.iibpas.com

EVALUATION OF ANTICANCER POTENTIAL OF ACORUS CALAMUS

BY INVITRO AND INSILCO ASSAY

\title{
SHARMILA R
}

Assistant Professor, Department of Biotechnology, Bishop Heber College, Trichirappalli-620017

*Corresponding Author: E Mail: sharmilabiotech81@gmail.com

Received 13 ${ }^{\text {th }}$ Dec. 2019; Revised $11^{\text {th }}$ Jan. 2020; Accepted $12^{\text {th }}$ Feb. 2020; Available online $1^{\text {st }}$ Aug. 2020

https://doi.org/10.31032/IJBPAS/2020/9.8.5160

ABSTRACT

Acorus calamus has been used as a medicinal plant in Asia from the last 2000 years. To investigate the anti-cancer activity of rhizome of A.calamus, the methanolic extracts of the rhizome were prepared. In this study anticancer effect of $A$. calamus was evaluated on breast cancer (MCF-7) cell line and ELF-5 by in vitro and Insilco method. The MTT assay were used to determine cytotoxicity against breast cancer cell line.MCF-7 cells were cultured in DMEM medium and incubated with different concentrations of A.calamus extract. The cell viability was assessed by MTT assay. A.calamus has decreased effect on malignant cells in a concentration dependent manner. Among the different concentration tested the higher concentration had a considerable effect for the inhibition of cancer cells. In case of insilico studies acitretin is a potent phytochemical of Acorus calamus that can effectively inhibit the target protein ELF-5.

\section{Keywords: Acorus calamus, MCF-7, ELF-5, breast cancer}

\section{INTRODUCTION}

Medicinal plants are the most important source of life saving drugs for the majority of the world's population. Plants have been an important source of medicine for thousands of years. Even today, the World Health Organization (WHO) estimates that up to $80 \%$ of people still rely mainly on traditional remedies such as herbs for their medicines. Throughout the history, secondary metabolites of plants have been utilized by humanity. There are approximately four major classes of 
secondary compounds that are significant to humans, viz. Alkaloids, phenyl propaniods, flavonoids and terpenoids

One of the most important sources of new drugs are herbal medicine and in this regard, attention on plant components which have anti-cancer properties has been increased $[1,2]$. A wide variety of secondary metabolites obtained from plants are tested for their ability to treat cancer. Various anti-cancer drugs from plants are known to be effective against proliferating cells. They exhibit cytotoxic effects either by damaging DNA or by blocking the formation of mitotic spindle during stages of cell division [3]. However most of the cytotoxic drugs exhibit side effects, and hence, there is a need for drugs that are efficient and have less side effects [4]. The use of plant products in the treatment of cancer has been of recent interest [5]. Traditional medicine is mainly based on plant-derived substances which possess a variety of primary health care properties [6].

Many drugs that are used for cancer treatment are at present obtained from plant sources. These include the well-known vincaalkaloids, vincristine and vinblastin, isolated from Catharanthus roseus, etoposide and teniposide, derivatives of epipodophyllotoxin, isolated from Podophyllum, and several others [7, 8]. Acorus calamus (A. calamus) has been used as a medicinal plant in Asia for various treatments for the last 2000 years. Acorus calamus (A.calamus) which is also known as sweet flag (Araceae family) [9] is a beneficial and medicinal plant that has been used in herbal therapies and human health care preparations in the Asia for a long time.

The origin of A.calamus is thought to be India, through now it is also found in other parts of the world including Asia, Sri Lanka, Burma, Japan, China, southern Russia, Europe, and northern USA.This plant is a perennial plant and was spread outside its native area in Asia [6]. Though the present study aimed to investigate the anti-cancer activity of rhizome of $A$. calamus, through the methanolic extracts of the rhizome were prepared and their effects were analyzed by the MTT assay on MCF-7 cell lines.

\section{MATERIALS AND METHODS}

\section{Collection of plants}

Acorus calamus rhizomes were obtained from its natural habitat in Tiruchirappalli region, Tamil Nadu, India in the month of December, 2017. They were 
shade-dried, powdered, sieved and stored prior to further use.

\section{Extraction}

$20 \mathrm{~g}$ of the dried rhizome derived from the plant A.calamus was grounded and changed into a coarse powder. The powder was put in a Soxhlet extractor harboring 500 $\mathrm{mL}$ of methanol and kept for 8 hours. This procedure was repeated three times. The extracts were concentrated within a rotary evaporator for $75 \mathrm{~min}$ (vacuum condition, $60^{\circ} \mathrm{C}$ ) and then stored at $4{ }^{\circ} \mathrm{C}$. The extracts of A. calamus were dissolved in dimethyl sulphoxide (DMSO) for preparations of different concentrations were tested for cytotoxicity.

\section{Phytochemical analysis}

The crude powdered plant samples were taken for preliminary phytochemical screening to identify the presence of secondary metabolites (alkaloids, flavonoids, saponins, tannins, carbohydrates, aminoacids, steroids, glycosides, terpenoids) using standard established methods [10].

\section{Antimicrobial Activity Disc Diffusion}

\section{Method}

In vitro antimicrobial was carried out by disc diffusion technique in what man no;1 filter paper disc with $4 \mathrm{~mm}$ diameter were impregnated with known amount test sample of the disc were loaded each with
$10 \mu 1$ of the extract by the first applying $5 \mu 1$ with the pipette allowed to evaporate than applying another $5 \mu 1$ than drying again. The positive control contained a standard antibiotic disc sterile disc use as negative control. The impregnated disc along with control (streptomycin) was kept at the center of agar plates, seeded with test bacterial cultures. The discs were then placed individually using a sterile forceps in appropriate grids which were marked on the under surface of the plates Petri plates and kept for incubation at room temperature for 24 hours. After incubation plates were observed for zones of inhibition and recorded in millimeters.

\section{MTT Assay}

The anticancer activity of samples on MCF-7 was determined by the MTT assay [11]. Cells $\left(1 \times 10^{5} /\right.$ well $)$ were plated in $1 \mathrm{ml}$ of medium/well in 24-well plates (Costar Corning, Rochester, NY). After $48 \mathrm{hr}$ incubation the cells reached the confluence. Then, the cells were incubated in the presence of various concentrations of the samples in $0.1 \%$ DMSO for $48 \mathrm{~h}$ at $37^{\circ} \mathrm{C}$. After removal of the sample solution and washing with phosphate-buffered saline $(\mathrm{pH}$ 7.4), $200 \mu \mathrm{l} /$ well $(5 \mathrm{mg} / \mathrm{ml})$ of $0.5 \% 3-(4,5$ dimethyl-2-thiazolyl)-2, 5-diphenyl-tetrazolium bromide cells (MTT) solution 
was added. After 4h incubation, $0.04 \mathrm{M} \mathrm{HCl} /$ isopropanol were added. Viable cells were determined by the absorbance at $570 \mathrm{~nm}$. Measurements were performed and the concentration required for a $50 \%$ inhibition of viability $\left(\mathrm{IC}_{50}\right)$ was determined. The absorbance at $570 \mathrm{~nm}$ was measured with a UV- Spectrophotometer using wells with untreated cells as blanks. The effect of the samples on the proliferation of MCF-7was expressed as the \% cell viability, using the following formula:

$\%$ cell viability $=A_{570}$ of treated cells $/ A_{570}$ of control cells $\times 100$

Molecular Docking

Target protein selection:
Bioinformatics is seen as an emerging field with potential to significantly improve how drugs are found, brought to the clinical trials and eventually released to the marketplace. Protein targets (ELF5) were downloaded from database Protein Data bank (PDB). 1WWX is the PDB ID of the target protein of ELF5.

\section{Preparation of Ligand}

\section{Chemical screened}

Chemicals of beta asarone and their similar compounds namely Salicyclic acid, Glycolic acid, Tazarotene, Podophyllotoxin, Etretinate, Acitretin, from the Acorus calamus were screened against the ELF5.

\section{Structure of $\boldsymbol{\beta}$-asarone}

Structure Glycolic acid

\section{Structure of salicylic acid}

Structure of Tazarotene 


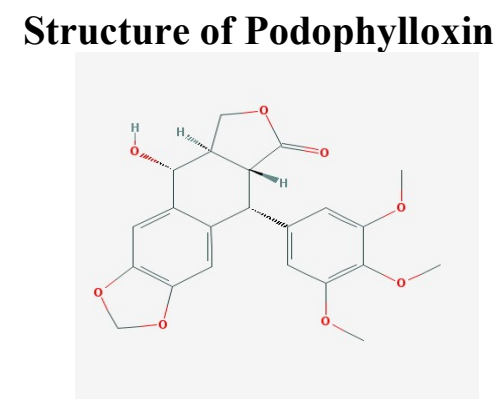

\section{Structure of Acitretin}

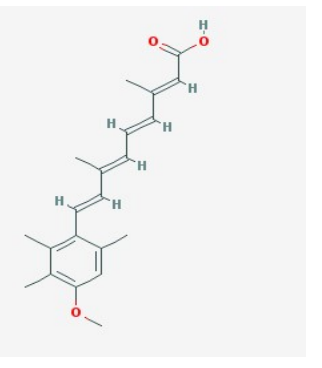

Quantitative Structure Activity

\section{Relationship (QSAR) Studies}

Quantitative Structure Activity Relationships (QSARs) are mathematical models that are used to predict measures of toxicity from physical characteristics of the structure of chemicals (known as molecular descriptors). Acute toxicities (such as the concentration that causes half of a fish population to die) are one example of the toxicity measures that may be predicted from QSARs. Simple QSAR models calculate the toxicity of chemicals using a simple linear function of molecular descriptors:

Toxicity=

$\mathbf{a x}_{1}+\mathbf{b x}_{2}+\mathbf{c}$

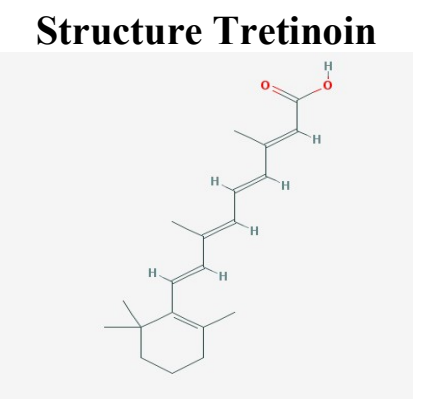

Structure ELF-5

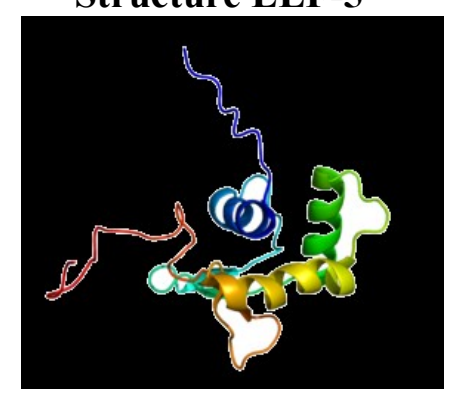

Where $x_{1}$ and $x_{2}$ are the independent descriptor variables and $a, b$, and $c$ are fitted parameters.

\section{RESULT AND DISSCUSSION}

Cancer therapy is to eliminate clonogenic cells in a tumor recurrence depends on continued growth of surviving clonogens. This leads to the conclusion that other modes of cell death are also important in the response to treatment. The breast cancer cell line MCF-7 is one of the important cell line models with deficient of apoptotic machinery and are interestingly resistant to most drugs. This cell line model was used in the present study to identify potential activity of Invitro assay for anticancer activity. 
The MCF-7 cells were seeded and the cytotoxic effects of various concentration of A.calamus were determined. The MTT cytotoxicity of A.calaums on MCF-7 cells was carried out in triplicate. The cell viability was examined for different concentration with the untreated control samples. There was a gradual increase in the effects of A.calamus observed in the graph for 24,48 and $72 \mathrm{hrs}$. Viable cells were determined by the absorbance at $570 \mathrm{~nm}$. Measurements were performed and the concentration required for a $50 \%$ inhibition of viability $\left(\mathrm{IC}_{50}\right)$ was determined. The absorbance at $570 \mathrm{~nm}$ was measured with a UVSpectrophotometer using wells with untreated cells as blanks. Thus the apoptotic cells and normal cells could be easily differentiated. Therefore in this study, A.calamus induced apoptosis in human breast cancer cell line (MCF-7). From this study, A.calamus could be suggested as a potent chemotherapeutic drug for cancer treatment (Table 1) (Figure 1-6).

Results were carried out by various concentration of methanolic extract Acorus calamus, the maximum inhibition was observed by $125 \mu \mathrm{g} / \mathrm{ml}$ at $72 \mathrm{hrs}$. The various concentration of result was showed in the Figure 5c.

Phytochemical Analysis:
The methanol extract of Sweet flag (Acorus calamus) showed the presence of Tannins, Flavanoids, Terperoids, Amino acid and absence of alkaloids, Suponins, Phenols, Steroids, Cardiac glycosides, Carbohydrate, Reducing sugar and monosaccharides (Table 2).

\section{Antimicrobial Activity}

A.calamus has very significant antimicrobial activity against gram positive and gram negative bacteria. Antimicrobial activity of root extract of A.calamus may be due to Flavanoids, Tannins, Salicylic acid, and Acitredin which have antibacterial properties. The result supported that plant extract was found to be inhibitory for both gram positive and gram negative bacteria. The antibacterial activity of methanolic extract of A.calamus, were carried out by disc method, the maximum inhibition of the zone was observed in Escherichia coli (Figure 7) (Table 3).

\section{Molecular Docking Studies against Breast Cancer Causing Protein ELF5:}

Seven compounds are derived from Acorus calamus (L.) was docked with E7 like Factor (ELF5). The docked ligand molecules were selected based on a energy and good interaction with the active site residues and the results are shown in Table 5. Out the seven ligand molecules, five showed the 
activation energy of greater than $-80 \mathrm{~K}$ $\mathrm{Cal} / \mathrm{mol}$ and remaining two compounds exhibited the values $<80 \mathrm{~K} \mathrm{Cal} / \mathrm{mol}$. The highest activation energy $(-104.4 \mathrm{~K} \mathrm{Cal} / \mathrm{mol})$ was found in acitretin (Figure 1a) and followed by Salicyclic acid, Glycolic acid, Tazarotene, Podophyllotoxin, Tretinoin, Acitretin ( -79.1, -81.2, -84.1, -84.5, -93.8, 104.4). While, lowest energy of $-75.6 \mathrm{~K}$ $\mathrm{Cal} / \mathrm{mol}$ was found in $\beta$-asarone. Thus, the In silico docking results, revealed that Acorus calamus derived compounds have the great potential against inhibition of E7Like Factor (ELF5). QSAR Studies were carried out by using online tool Alcula regression. From the overall studies it is found that the A.calamus compounds acted against the target E74 like factor thereby inhibiting it. The best compound identified was acotretin since it the Lipinski's rule and exhibited drug likeliness and interacted with the binding site residues and exhibited a minimal energy to be stable. QSAR results also suggested that the compound fitted on the best line and hence had a better relationship of structure and activity (Table 4).

$\boldsymbol{\beta}$-Asarone has its energy level -75.6, compare with their similar compounds, like Salicyclic acid etc, so far Acorus calamus is best to prefer for cancer research as well as cancer treatment (Figure 8, 9).

Table 1: Anticancer effect of Sample on MCF-7 Cell line-MTT Assay

\begin{tabular}{|c|c|c|c|c|c|c|c|c|}
\hline \multirow[t]{2}{*}{ S. No } & \multirow[t]{2}{*}{$\begin{array}{l}\text { Concentration } \\
\qquad(\mu \mathrm{g} / \mathrm{ml})\end{array}$} & \multirow[t]{2}{*}{ Dilutions } & \multicolumn{3}{|c|}{$\begin{array}{c}\text { Absorbance } \\
\text { (O.D) }\end{array}$} & \multicolumn{3}{|c|}{ Cell viability (\%) } \\
\hline & & & $24 \mathrm{hr}$ & $48 \mathrm{hr}$ & $72 \mathrm{hr}$ & $24 \mathrm{hr}$ & $48 \mathrm{hr}$ & $72 \mathrm{hr}$ \\
\hline 1 & 1000 & Neat & 0.09 & 0.07 & 0.06 & 14.28 & 10.76 & 8.82 \\
\hline 2 & 500 & $1: 1$ & 0.17 & 0.13 & 0.10 & 26.98 & 20.00 & 14.70 \\
\hline 3 & 250 & $1: 2$ & 0.24 & 0.20 & 0.19 & 38.09 & 30.76 & 27.94 \\
\hline 4 & 125 & $1: 4$ & 0.32 & 0.27 & 0.25 & 50.79 & 41.53 & 36.76 \\
\hline 5 & 62.5 & $1: 8$ & 0.39 & 0.31 & 0.31 & 61.90 & 47.69 & 45.58 \\
\hline 6 & 31.2 & $1: 16$ & 0.44 & 0.37 & 0.36 & 69.84 & 56.92 & 52.94 \\
\hline 7 & 15.6 & $1: 32$ & 0.49 & 0.42 & 0.40 & 77.77 & 64.61 & 58.82 \\
\hline 8 & 7.8 & $1: 64$ & 0.55 & 0.47 & 0.43 & 87.30 & 72.30 & 63.23 \\
\hline 9 & Cell control & - & 0.63 & 0.65 & 0.68 & 100 & 100 & 100 \\
\hline
\end{tabular}




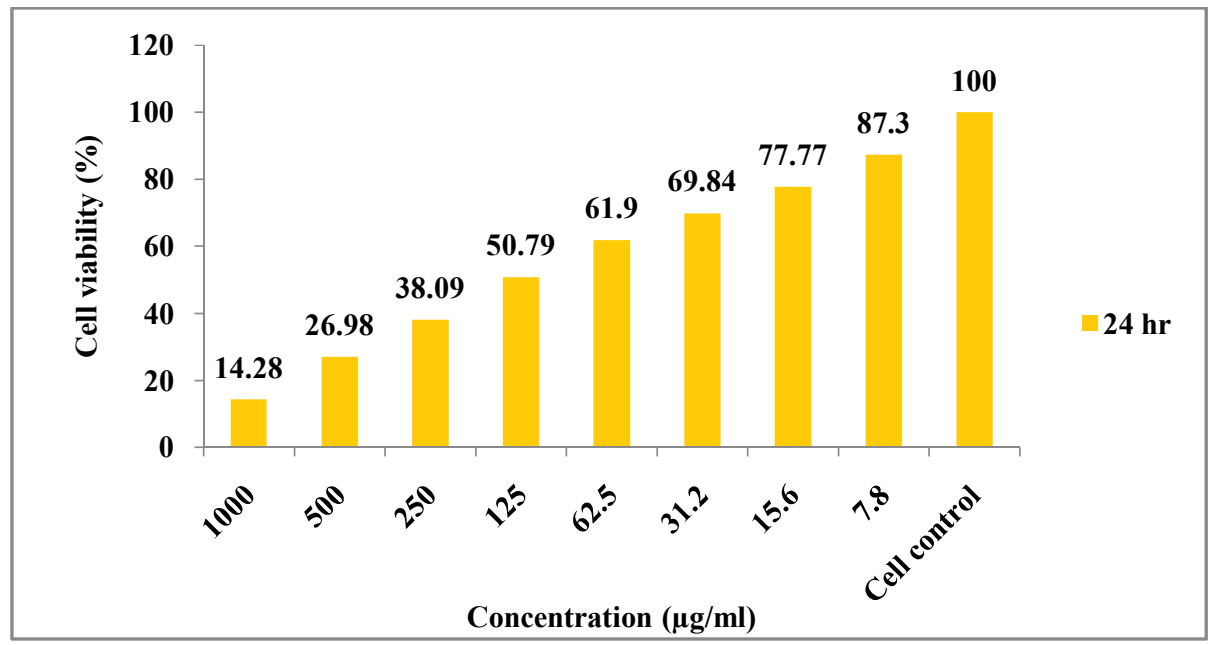

Figure 1: Shows the cell viability concentration at $24 \mathrm{hrs}$

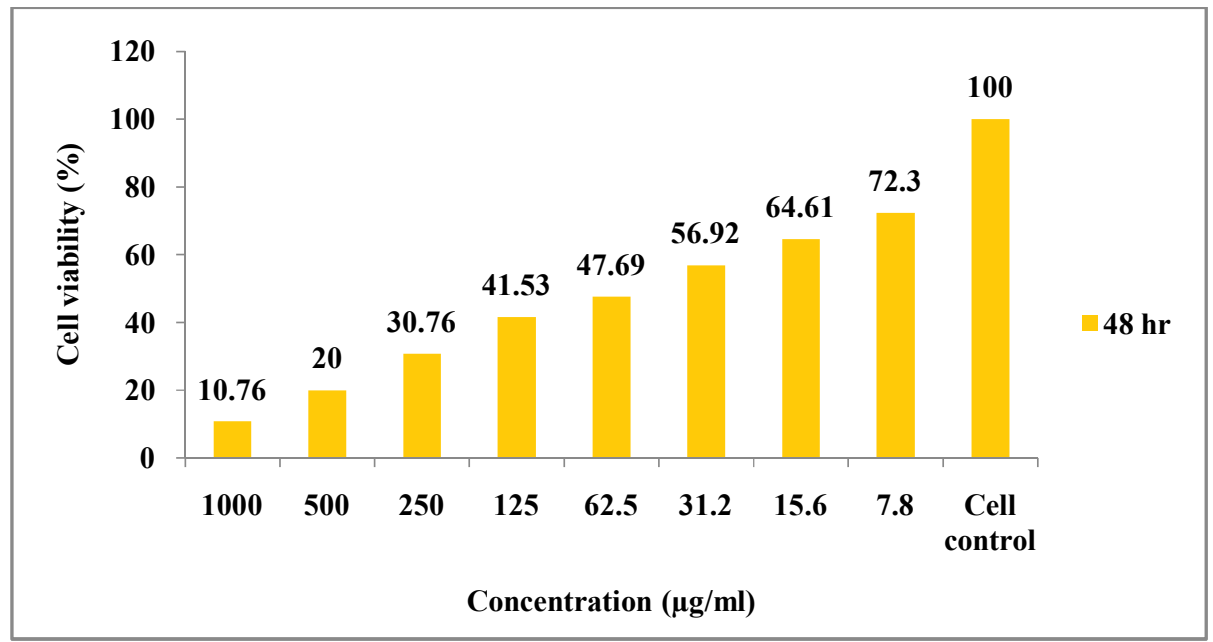

Figure 2: Shows the cell viability concentration at $48 \mathrm{hrs}$

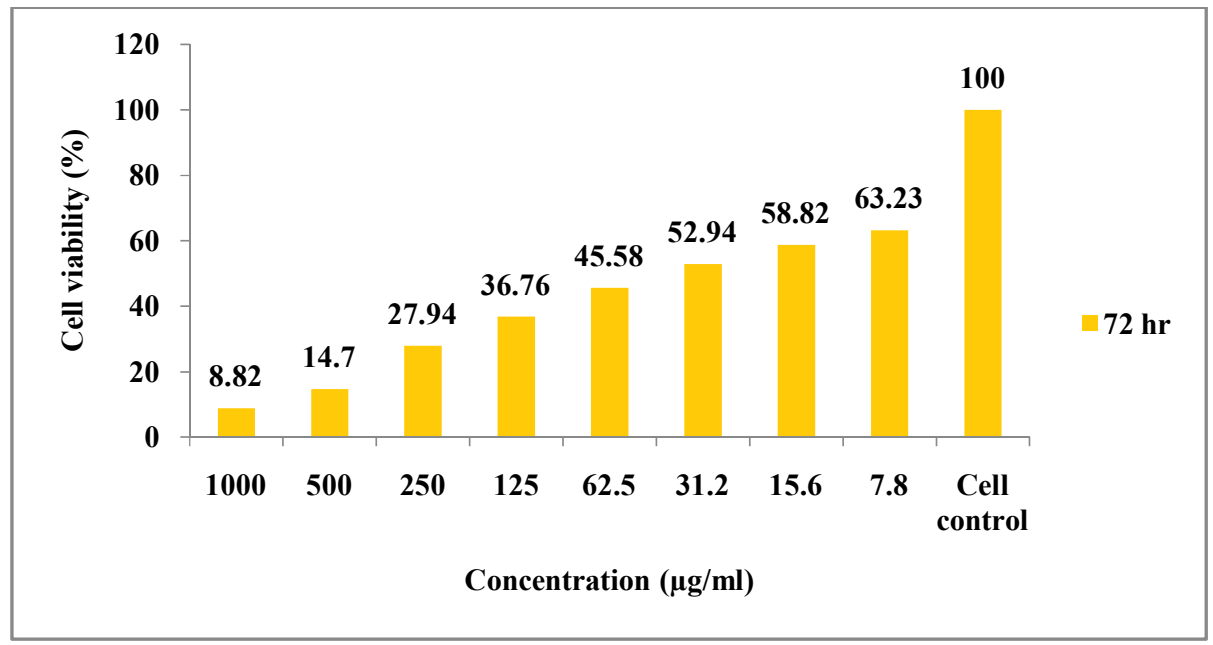

Figure 3: Shows the cell viability concentration at $72 \mathrm{hrs}$ 


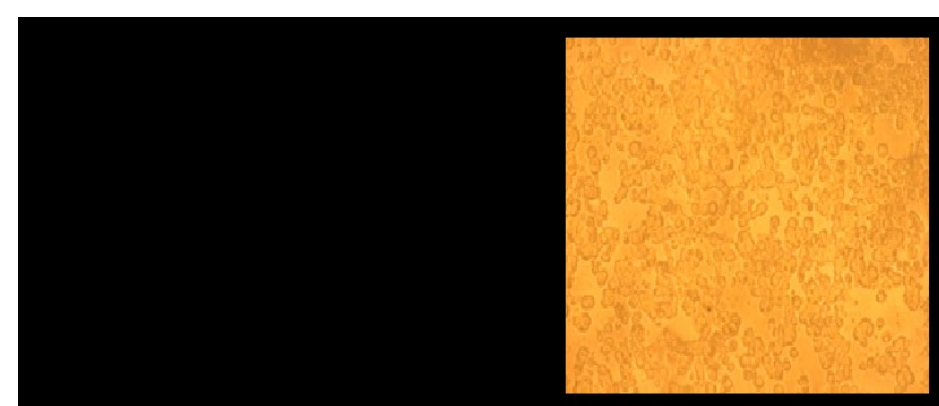

Figure 1

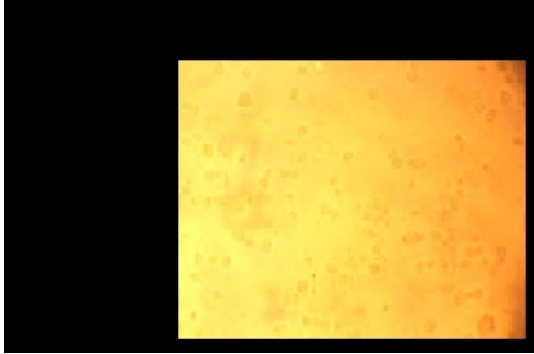

Figure 4a: 24hrs

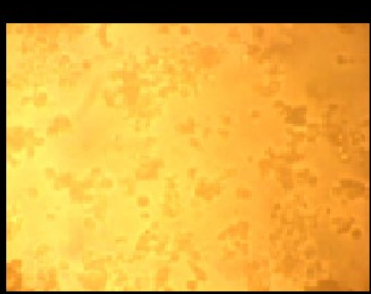

Figure 4b: 48hrs

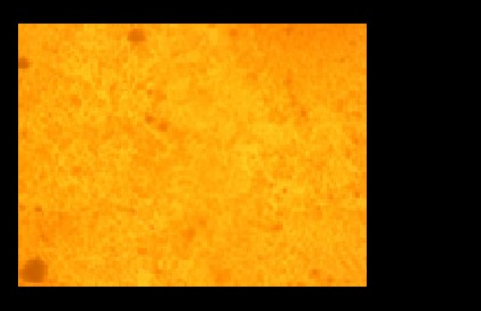

Figure 4c: $72 \mathrm{hrs}$

Figure 4: Cell line was treated with $1000 \mu \mathrm{g} / \mathrm{ml}$ of Acorus calamus in different incubation period

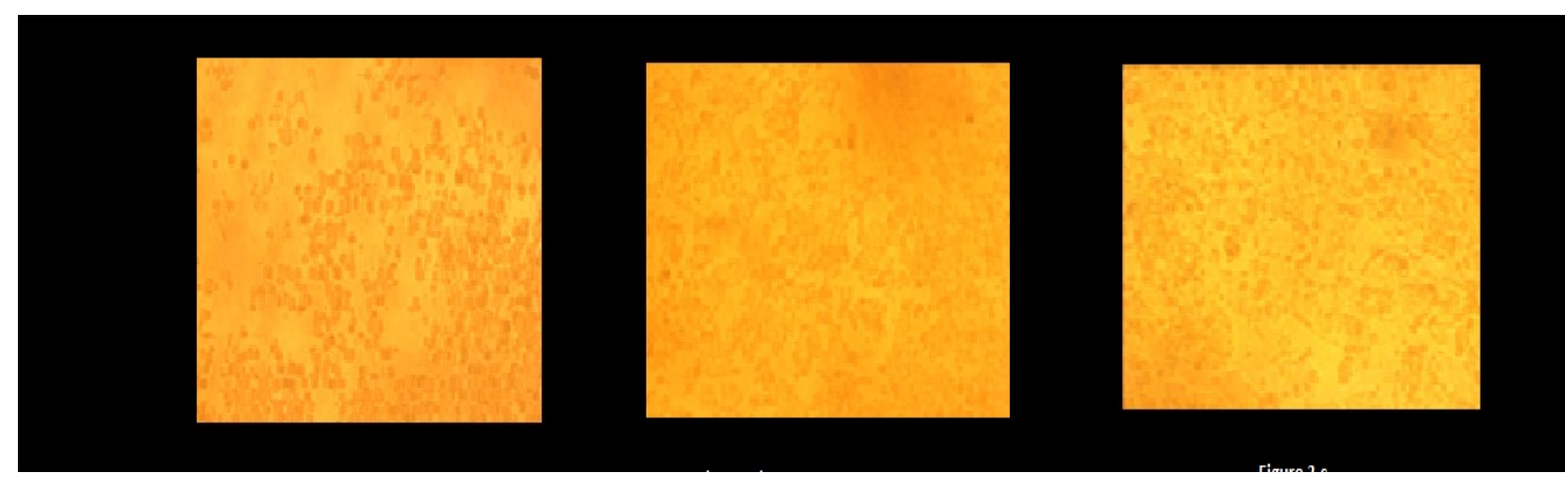

Figure 5a: 24hrs

Figure 5: 48hrs

Figure 5c: $72 \mathrm{hrs}$

Figure 5: Cell line was treated with $125 \mu \mathrm{g} / \mathrm{ml}$ of Acorus calamus in different incubation period

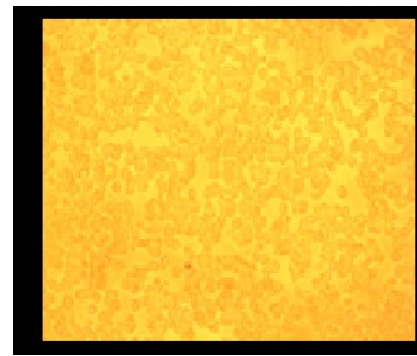

Figure 6a: 24hrs

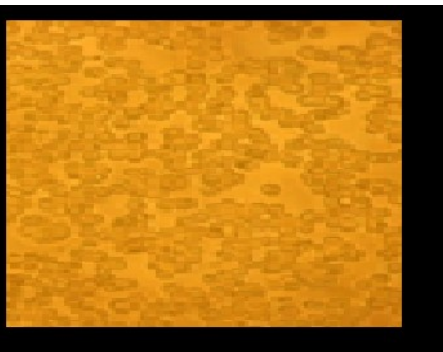

Figure6c: $72 \mathrm{hrs}$

Figure 6: Cell line was treated with $62.5 \mu \mathrm{g} / \mathrm{ml}$ of Acorus calamus in different incubation period 
Table 2: Photochemical analysis of methanol extract of Acorus calamus

\begin{tabular}{|c|c|}
\hline Phytoconstituents & Presence / Absence \\
\hline Alkaloids & - \\
\hline Tannins & + \\
\hline Suponins & - \\
\hline Phenols & - \\
\hline Steroids & - \\
\hline Cardiac glycosides & + \\
\hline Flavanoids & + \\
\hline Terperoids & + \\
\hline Amino acid & - \\
\hline Carbohydrate & - \\
\hline Reducing sugar & - \\
\hline Mono saccharides & \\
\hline
\end{tabular}

Table 3: Result for antimicrobial activity methanol extract of Acorus calamus

\begin{tabular}{|c|c|c|c|c|c|}
\hline \multirow[b]{2}{*}{ Name of the micro organisms } & \multicolumn{5}{|c|}{ Zone of inhibition (cm) } \\
\hline & $\begin{array}{c}\text { Positive } \\
\text { control } \\
\text { antibiotic } \\
\text { (mm) }\end{array}$ & $\begin{array}{c}\text { Negative } \\
\text { control } \\
(\mathrm{mm})\end{array}$ & $\begin{array}{c}\text { Conc. } \\
0.5 \mu \mathrm{l} / \text { well } \\
(\mathrm{mm})\end{array}$ & $\begin{array}{c}\text { Conc. } \\
10 \mu \mathrm{l} / \text { well } \\
(\mathrm{mm})\end{array}$ & $\begin{array}{c}\text { Conc. } \\
\text { 15 } \mu \mathrm{l} / \mathrm{well} \\
(\mathrm{mm})\end{array}$ \\
\hline Escherichia coli & 1.5 & - & 0.1 & 0.2 & 1.5 \\
\hline Klebsiella pnemoniae & 1.6 & - & 0.4 & 0.6 & 1.4 \\
\hline Pseudomonas aeruginosa & 1.2 & - & 0.2 & 0.4 & 0.6 \\
\hline Protease mirabilis & 1.0 & - & - & 0.1 & 0.2 \\
\hline Entrobactor & 1.2 & - & 0.1 & 0.3 & 0.6 \\
\hline
\end{tabular}

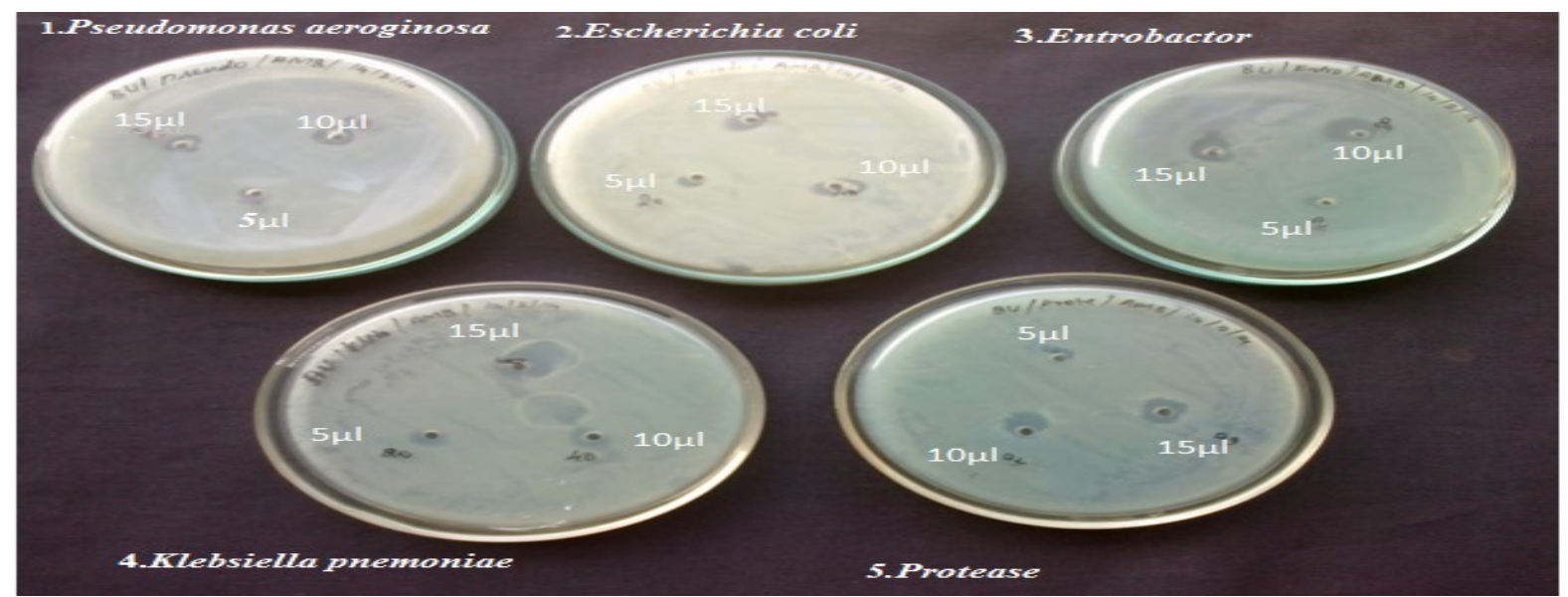

Figure 7: Antimicrobial activity of A.calamus

Table 4: Binding Energy For The Best Compound Docked Against ELF5

\begin{tabular}{|c|c|c|c|c|c|c|}
\hline S. No & $\begin{array}{c}\text { Phytocompounds present } \\
\text { in Acorus calamus }\end{array}$ & $\begin{array}{c}\text { Binding energy } \\
\text { ( k cal/mol) }\end{array}$ & vdw & hbond & elec & Interacting residues \\
\hline 1. & B-asarone & -75.6 & -73.66 & -5.98 & 0 & ARG 54 \\
\hline 2. & Salicyclic acid & -79.1 & -73.60 & -5.90 & 0 & HIS 10, ASP17 \\
\hline 3. & Glycolic acid & -81.2 & -65.21 & -11.85 & 0 & HIS 10 \\
\hline 4. & Tazarotene & -84.1 & -72.35 & -6.24 & 0 & HIS 10 \\
\hline 5. & Podophyllotoxin & -84.5 & -62.36 & -14.41 & 0 & HIS 10, ASP 17 \\
\hline 6. & Tretinoin & -93.8 & -60.87 & -14.27 & 0 & HIS 10 \\
\hline 7. & Acitretin & -104.4 & -74.62 & -6.12 & 0 & HIS 10 \\
\hline
\end{tabular}



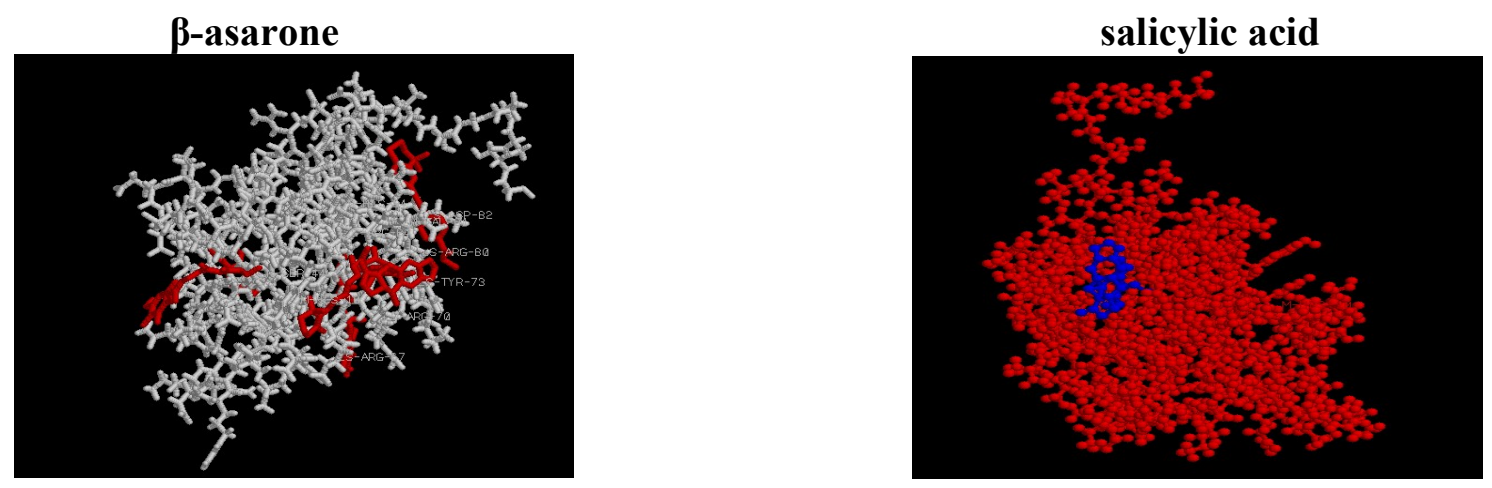

Glycolic acid

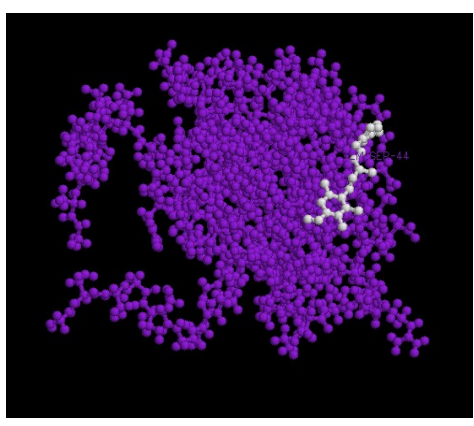

podollotoxin

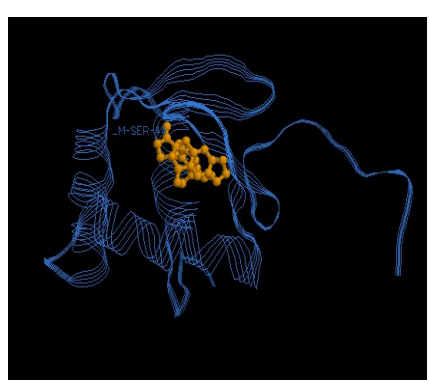

Tretinoin

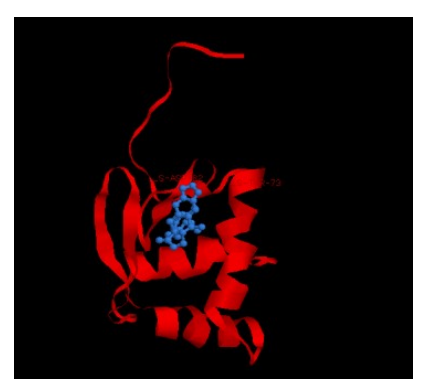

Figure 8
Tazardene

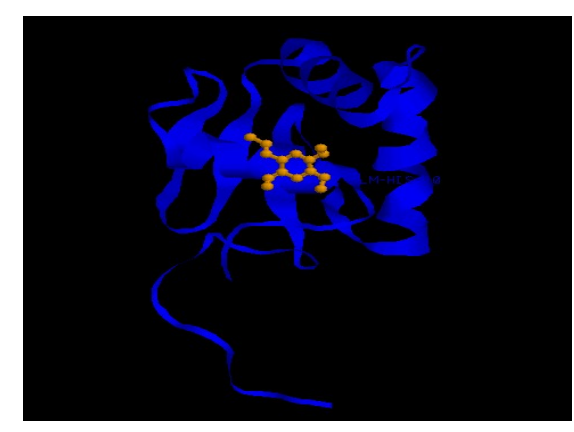

acitretin

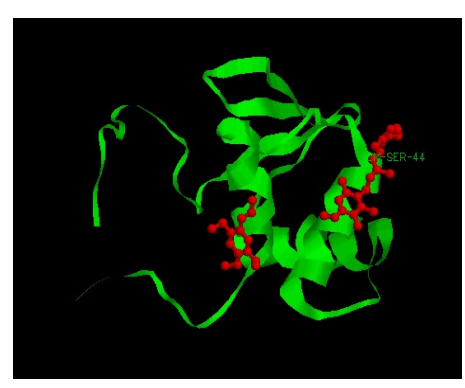

Table 5: Predicted adme properties of the acitretin compound

\begin{tabular}{|c|c|c|c|c|c|c|}
\hline Compound & Molecular Weight & Log P & HBDH & MNO & TPSA total & Rule of 5 \\
\hline B-asarone & 208.259 & 2.902 & 0.000 & 3.000 & 27.690 & 0.000 \\
\hline Salicyclic acid & 208.259 & 2.902 & 0.000 & 3.000 & 27.690 & 0.000 \\
\hline Glycolic acid & 212.247 & 2.010 & 0.000 & 4.000 & 36.920 & 0.000 \\
\hline Tazarotene & 208.251 & 2.850 & 0.000 & 3.000 & 27.690 & $\mathbf{0 . 0 0 0}$ \\
\hline Podophyllotoxin & 236.313 & 2.971 & 0.000 & 3.000 & 27.690 & 0.000 \\
\hline Tretinoin & 250.340 & 4.534 & 0.000 & 3.000 & 27.968 & $\mathbf{0 . 0 0 0}$ \\
\hline Acitretin & 222.286 & 3.432 & 0.000 & 3.000 & 2.708 & $\mathbf{0 . 0 0 0}$ \\
\hline
\end{tabular}




\section{CONCLUSION}

The study concludes that rhizome of Acorus calamus might be considered as a potential source of metabolites which could be developed as precursors for anti-cancer drugs. Isolation and purification of these active compounds are in prospect.

\section{Acknowledgments}

We are indebted to the management of Bishop Heber College who have supported profoundly in performing this work. We are also grateful to the Department of Biotechnology and Bioinformatics of Bishop Heber College for extending their extension services in helping with the software analysis.

\section{REFFERENCE}

[1] Dorai T, Aggarwal BB. Role of chemopreventive agents in cancer therapy. Cancer Lett. 2004; 215: 129140.

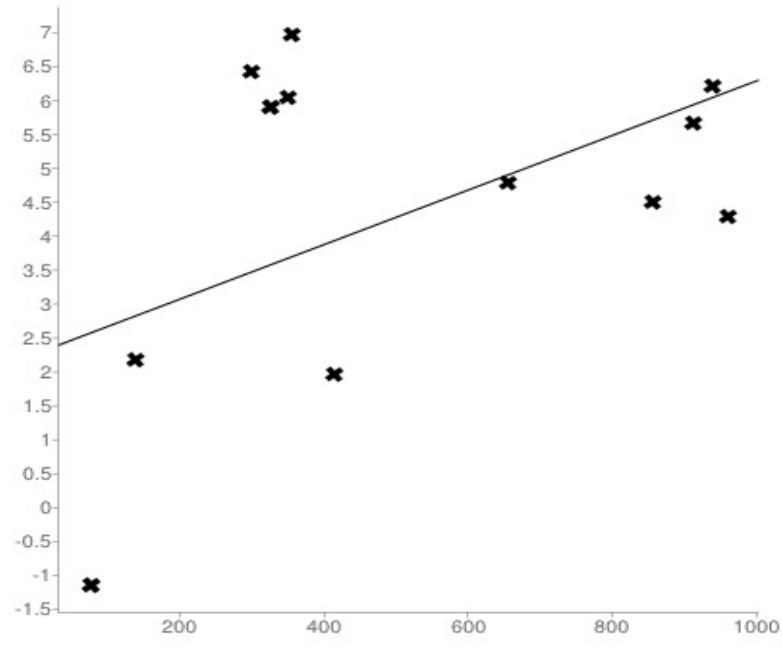

of A.calamu

[2] Gharaei R, Akrami H, Heidari S, Asadi MH, Jalili A. The suppression effect of Ferula gummosa Boiss extracts on cell proliferation through apoptosis induction in gastric cancer cell line. Eur J Integr Med. 2013; 5: 241-247.

[3] Gali-Muhtasib H, Bakkar N. Modulating cell cycle: current applications and prospects for future drug development. Curr Cancer Drug Targets. 2002; 2: 309-336.

[4] Sri devi. M., Vinothini.K., Sridhar.S., and Veronica shalini., In silico and In vitro Analysis of Acorus calamus in support for antibacterial activity, Advanced biotech, 12, 2012.

[5] Srividya AR., Aishwaria SN., and Vishnuvarthan VJ., Evaluation of Antioxidant, Antimicrobial And Cytotoxicity Activity of 
Hydroethanolic Extract And Its Fractions Of Acorus calamus Linn, international journal for pharmaceutical research scholars3, 2014.

[6] Balakumbahan R, Rajamani K, Kumanan K. Acorus calamus: An overview. J Med Plants Res. 2010; 4: 2740-2745.

[7] Cragg G.M, Schepartz S.A, Stuffness M, Grever M.R. The taxol supply crisis. New NCI policies for handling the large-scale production of novel natural product anticancer and antiHIV agents. J. Nat. Prod, 1993: 56: 1657-1668.

[8] Wang H.K. Plant-derived anticancer agents currently in clinical use or clinical trials. The Investigation Drugs Journal, 1998:1: 92-102.

[9] Meena AK, Rao MM, Singh A, Kumari S. Phytochemical and preliminary phytochemical studies on the rhizome of Acorus calamus Linn. Int J Pharm Pharm Sci. 2010; 2:130-131.

[10] Harborne JB, Phytochemical Methods, Chapman and Hall, Ltd., London, 1973. 9-188.

[11] Xi Zou, beta-asarone induces lovo colon cancer cell apoptosis by up- regulation of caspases through a mitochondrial pathway in vitro and in vivo, Asian Pacific Journal of Cancer Prevention, 2012.13. 